\title{
Potential causes of high performance of pure-oxygen aerobic granules in SBR under high organic loading condition
}

\author{
Pan F.H. ${ }^{1}$, Jiang Y.B. ${ }^{1,2,}{ }^{*}$, Huang K.X. ${ }^{2}$, Zhang X.X. ${ }^{1,3}$, Huang Y.J. ${ }^{2}$ and Wang X.Y. ${ }^{2}$ \\ ${ }^{1}$ Engineering Research Center of Biomembrane Water Purification and Utilization Technology of Education, Anhui University of \\ Technology, Ma'anshan, Anhui, 243032, China \\ 2Department of Environmental Science and Engineering, Anhui University of Technology, Ma'anshan, Anhui, 243032, China \\ ${ }^{3}$ Department of Civil Engineering, Anhui University of Technology, Ma'anshan, Anhui, 243032, China \\ Received: 17/08/2017, Accepted: 10/12/2017, Available online: 19/12/2017 \\ *to whom all correspondence should be addressed: e-mail: yongbin jiang@163.com
}

\section{Abstract}

Aerobic granules were cultivated using pure oxygen aeration (POAG) in SBR for wastewater treatment under high organic loading condition (HOLC) to reveal its performance and potential causes. Compared to conventional granules and activated sludge, mature POAG with more compact and dense structure were formed in a shorter term using pure-oxygen aeration in SBR. The system shows high and stable $\mathrm{COD}$ and $\mathrm{NH}_{4}{ }^{+}-\mathrm{N}$ removal efficiencies with an average value of $91 \%$ and $84 \%$, respectively, under HOLC. Adequate dissolved oxygen (DO) supplied by pure-oxygen aeration is the prerequisite explaining the elevated performance. POAG have more stable compact granular structure and elevated biomass than that of conventional biogranules and bioflocs under HOLC. High EPS content facilitate the formation of POAG and maintain its integrity and stability of spatial structure, which is in favor of biomass growth. Abundant catalase synthesized by its biomass ensure the ability to hydrolyze and mineralize organic substance under HOLC. A great deal of dehydrogenase secreted by POAG play a critical role in maintaining its metabolism under HOLC, which in turn enhance multiplication capacity of living organism in POAG and elevate removal performance of organic pollutants from wastewater.

Keywords: Pure-oxygen aerobic granules; High organic loading; Biomass; Catalase; Dehydrogenase; Wastewater treatment

\section{Introduction}

Aerobic granules have been regarded as a desirable biological material in wastewater treatment (Adav et al., 2008, 2009; Caudan et al., 2014; Li et al., 2008). It is characteristics of abundant biodiversity (Adav et al., 2009; Bernat et al., 2017; Meerburg et al., 2016), a dense and strong microbial structure (Adav et al., 2008; Moy et al., 2002), elevated activity of enzymes (Li and Chróst, 2006; Matyja et al., 2016; Tarjányi-Szikora et al., 2013; Yao et al., 2010, 2012; Zhang et al., 2016) and a great plenty of EPS secretion (Badireddy et al., 2010; Caudan et al., 2014; Liu et al., 2004; Zhao et al., 2016; Zhu et al., 2012), which makes it harbor good performance under HOLC.

High organic loading wastewater with complex ingredients and usually over $2000 \mathrm{mg} \mathrm{COD} \mathrm{L}^{-1}$ is a great challenge to prevail biological methods in wastewater treatment (Adav et al., 2010; Liu and Tay, 2015; Farzadkia et al., 2016; Moy et al., 2002; Pal et al., 2014; Ramos et al., 2016; Zhao et al., 2016; Zheng et al., 2006). Conventional aerobic granules are usually cultivated by air aeration (Adav et al., 2009; Caudan et al., 2014; Li et al., 2008). The granules subjected to HOLC usually disintegrate due to an obstacle of oxygen diffusion within granules (Adav et al., 2010; Liu and Tay, 2015; Zheng et al., 2006). Sufficient DO is essential to performance of aerobic granules under HOLC (Amand and Carlsson, 2012; Chen et al., 2003; Zheng et al., 2006). Pure oxygen aeration replacing air aeration significantly increased the oxygen mass transfer rate and stability of biological treating system and improved effluent quality 
(Bernat et al., 2017; Calderon et al., 2012; Rodríguez et al., 2012). Pure oxygen aeration is recently used in wastewater treatment by activated sludge and biofilms systems (Rodríguez et al., 2010; 2011). To our knowledge, little study on aerobic granules cultivated by pure-oxygen aeration and its performance under HOLC was carried out. In this work, pure-oxygen aerobic granules (POAG), pureoxygen activated sludge (POAS), air aerobic granules (AAG) and air aerobic sludge (AAS) were cultivated and used in treating high loading wastewater in SBR under different aeration conditions. The POAS, AAG and AAS were designed as three control experiments. The first objective of this study is the determination of performance of POAG in COD and $\mathrm{NH}_{4}{ }^{+}-\mathrm{N}$ removal under $\mathrm{HOLC}$. The second one is the investigation on biological characteristics of POAG responding to HOLC by observing micrographic morphology and measuring the EPS content, catalase and dehydrogenase activity and the biomass. The last one is the identification of potential causes of high performance of POAG in SBR under HOLC by analyzing correlation of biological characteristics and influent organic loading.
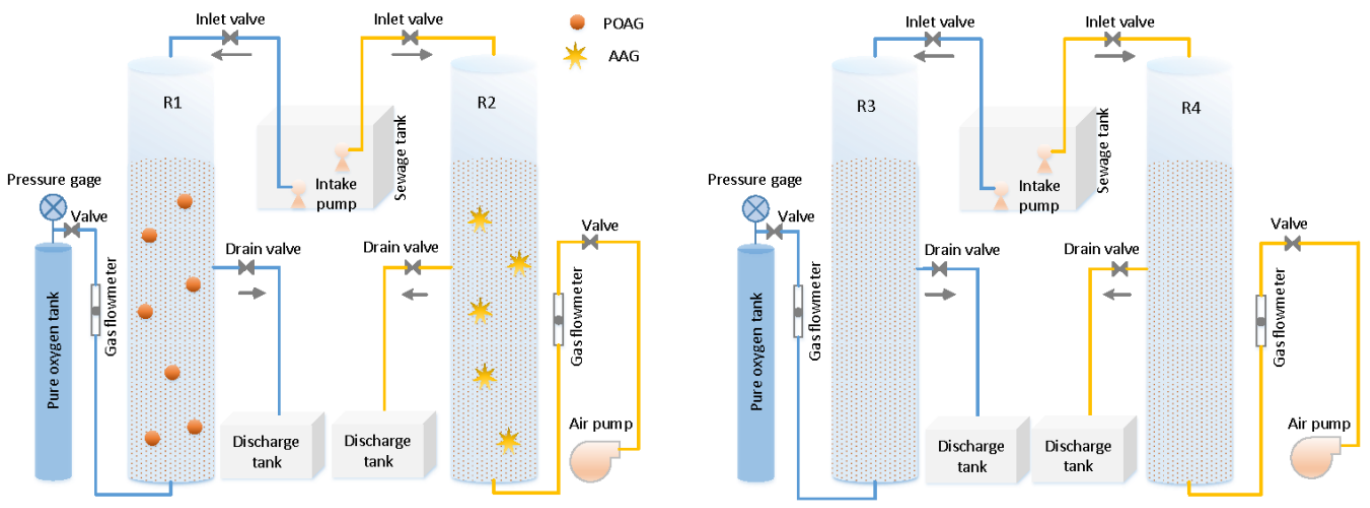

Figure 1. Schematic diagram of four SBR operations

\subsection{Cultivation and wastewater treatment}

Activated sludge taken from a municipal wastewater treatment plant in Ma'an Shan (East China) was used as the seed sludge in four SBRs. It had a mixed liquor suspended solids (MLSS) concentration of $3.3 \mathrm{~g} \mathrm{~L}^{-1}$ and a sludge volume index (SVI) of $99 \mathrm{~mL} \mathrm{~g}^{-1}$. Raw wastewater was taken from a sewage tank in the campus (Anhui University of Technology). The synthetic wastewater for initial sludge acclimation consisted of the raw wastewater and glucose as carbon and energy source. The experimental work in the four SBRs was divided into four stages: cultivation stage and high loading wastewater treating stages under HOLC

\section{Materials and methods}

\subsection{Experimental apparatus}

Four identical column-type SBRs $(120 \mathrm{~cm}$ high, $11 \mathrm{~cm}$ diameter) with a working volume of $7.6 \mathrm{~L}$ were used (Fig. 1). R1 and R3 were aerated using pure oxygen for the cultivation of POAG and POAS and corresponding wastewater treatments, respectively. R2 and R4 were aerated using air for the cultivation of AAG and AAS and corresponding wastewater treatments, respectively. The gas bubble diffusers were used in four SBRs and the volumetric flow rates were controlled with an identical value of $0.5 \mathrm{~L} \mathrm{~min}^{-1}$. The four SBRs were run under three cycles each day (9:00-15:00, 15:00-21:00, and 21:00-9:00). Each cycle consisted of 3 min of influent addition, 5-10 min of settling in R1 and R2 (aerobic granule cultivation) and 10 min of settling in R3 and R4 (activated sludge acclimatization), $3 \mathrm{~min}$ of effluent discharge, and the rest time for aeration. The volumetric exchange ratios in the reactors all were $50 \%$. 
The morphologies of aerobic granules and activated sludge were observed using an optical microscope (phenix ME200) and a digital camera (SONY, DSC-W730, Japan). The particle size of granules and sludge was measured in accordance with the report from Ramos et al. (2016). The amount of bacteria in suspension liquid collected on day $59,67,74$ and 81 in the four reactors were evaluated by the traditional plate colony counting method (Adav et al., 2009; Meerburg et al., 2016; Yao et al., 2010). The samples for analyses of EPS, catalase and dehydrogenase activities in sludge and granules were collected at the end of each SBR cycle. The EPS were extracted using a heat extraction method (Zhao et al., 2016). The polysaccharides (PS) content in the EPS was measured using the Anthrone

Table 1. Influent characteristics of R1, R2, R3 and R4 method (Adav et al., 2008) with glucose as the standard. The protein (PN) content in the EPS was determined following the Lowry method using bovine serum albumin (Adav et al., 2008; Zhu et al., 2012). The sum of PS and PN was taken as the amount of total EPS. Catalase activity was defined as the consumption of $\mathrm{H}_{2} \mathrm{O}_{2}$ per $\mathrm{g}$ activated sludge per min using an ultraviolet spectrophotometer (UV3600) ( $\mathrm{mgH}_{2} \mathrm{O}_{2} \mathrm{~g}^{-1} \mathrm{~min}^{-1}$ ) (Yao et al., 2010; 2012). Dehydrogenase activity was measured by the reduction amount of 2,3,5triphenyltetrazolium chloride (TTC) with a spectrophotometry (722 S) ( $\mathrm{mg} \mathrm{TF} \mathrm{g}^{-1} \mathrm{~h}^{-1}$ ) and the detailed steps were performed as previously described (Matyja et al., 2016).

\begin{tabular}{|c|c|c|c|c|c|c|c|c|c|c|c|}
\hline \multirow[b]{2}{*}{ Phases } & \multirow[b]{2}{*}{ Days } & \multirow[b]{2}{*}{ Reactors } & \multicolumn{4}{|c|}{ Nutrients composition } & \multicolumn{5}{|c|}{ Influent parameters } \\
\hline & & & $\begin{array}{c}\text { Glucose } \\
\text { (g) }\end{array}$ & $\begin{array}{c}\mathrm{NH}_{4} \mathrm{Cl} \\
\text { (g) }\end{array}$ & $\begin{array}{c}\mathrm{KH}_{2} \mathrm{PO}_{4} \\
\text { (g) }\end{array}$ & $\begin{array}{c}\mathrm{CaCl}_{2} \\
\text { (g) }\end{array}$ & $\begin{array}{c}\text { COD } \\
\left(\mathrm{mg} \mathrm{L}^{-1}\right)\end{array}$ & $\begin{array}{l}\mathrm{NH}_{4}{ }^{+}-\mathrm{N} \\
\left(\mathrm{mg} \mathrm{L}^{-1}\right)\end{array}$ & $\begin{array}{c}\mathrm{TP} \\
\left(\mathrm{mg} \mathrm{L}^{-1}\right)\end{array}$ & $\begin{array}{c}\mathrm{Ca}^{2+} \\
\left(\mathrm{mg} \mathrm{L}^{-1}\right)\end{array}$ & $\begin{array}{l}\text { Influent loading } \\
\left(\operatorname{kgCOD~m}^{-3} \mathrm{~d}^{-1}\right)\end{array}$ \\
\hline \multirow{4}{*}{$\begin{array}{l}\text { Cultivation } \\
\text { stage }\end{array}$} & \multirow{4}{*}{$1-60$} & $\mathrm{R} 1$ & 9 & 1 & 0.4 & 3 & 1000 & 50 & 10 & $100-250$ & 1.51 \\
\hline & & $\mathrm{R} 2$ & 9 & 1 & 0.4 & 3 & 1000 & 50 & 10 & $100-250$ & 1.51 \\
\hline & & R3 & 9 & 1 & 0.4 & None & 1000 & 50 & 10 & $5-100$ & 1.51 \\
\hline & & R4 & 9 & 1 & 0.4 & None & 1000 & 50 & 10 & $5-100$ & 1.51 \\
\hline \multirow{4}{*}{ HOLC1 } & \multirow{4}{*}{$61-67$} & $\mathrm{R} 1$ & 14 & 1 & 0.4 & 3 & 1500 & 50 & 10 & 100 & 2.49 \\
\hline & & $\mathrm{R} 2$ & 14 & 1 & 0.4 & 3 & 1500 & 50 & 10 & 100 & 2.49 \\
\hline & & R3 & 14 & 1 & 0.4 & None & 1500 & 50 & 10 & 5 & 2.49 \\
\hline & & R4 & 14 & 1 & 0.4 & None & 1500 & 50 & 10 & 5 & 2.49 \\
\hline \multirow{4}{*}{ HOLC2 } & \multirow{4}{*}{$68-74$} & $\mathrm{R} 1$ & 22 & 1 & 0.4 & 3 & 2300 & 50 & 10 & 100 & 3.60 \\
\hline & & $\mathrm{R} 2$ & 22 & 1 & 0.4 & 3 & 2300 & 50 & 10 & 100 & 3.60 \\
\hline & & R3 & 22 & 1 & 0.4 & None & 2300 & 50 & 10 & 5 & 3.60 \\
\hline & & R4 & 22 & 1 & 0.4 & None & 2300 & 50 & 10 & 5 & 3.60 \\
\hline \multirow{4}{*}{ HOLC3 } & \multirow{4}{*}{$75-81$} & $\mathrm{R} 1$ & 29 & 1 & 0.4 & 3 & 3000 & 50 & 10 & 100 & 4.57 \\
\hline & & $\mathrm{R} 2$ & 19 & 1 & 0.4 & 3 & 2000 & 50 & 10 & 100 & 3.07 \\
\hline & & R3 & 29 & 1 & 0.4 & None & 3000 & 50 & 10 & 5 & 4.57 \\
\hline & & R4 & 19 & 1 & 0.4 & None & 2000 & 50 & 10 & 5 & 3.07 \\
\hline
\end{tabular}

\section{Results and discussion}

\subsection{Formation and performance of POAG}

Stable granulation for mature POAG was obtained on day 45 (Fig. 2a), achieving an average granule size of $5 \pm 2 \mathrm{~mm}$ and the SVI of $35.4 \mathrm{~mL} \mathrm{~g}^{-1}$ (Pan et al., 2014). The granulation process of AAG was relatively slower than POAG, taking 52 days (Fig. 2b), with an average particle size of $3 \pm 2 \mathrm{~mm}$ and the SVI of $53.8 \mathrm{~mL} \mathrm{~g}^{-1}$ (Pan et al., 2014). The POAS and AAS had a floc size less than $0.1 \mathrm{~mm}$ with a high SVI of $79.3 \mathrm{~mL}$ $\mathrm{g}^{-1}$ and $139.7 \mathrm{~mL} \mathrm{~g}^{-1}$ at the same time (Pan et al., 2014).
More compact structure of POAG was observed than those of POAS, AAG and AAS (Fig. 2). The reactor operations failed due to disintegration of granules in $\mathrm{R} 2$ and excess foaming in R4 at beginning of HOLC2 stage. Thus, the HOLC were adjusted to $3.07 \mathrm{~kg} \mathrm{COD} \mathrm{m}^{-3} \mathrm{~d}^{-1}$ for them at HOLC3 stage (Table 1).

The removal efficiencies of COD and $\mathrm{NH}_{4}{ }^{+}-\mathrm{N}$ by the four SBRs during the processes of cultivation and treatment under HOLC are showed in Figure 3. The mature POAG in R1 showed excellent and stable performances in COD and 
$\mathrm{NH}_{4}{ }^{+}-\mathrm{N}$ removal with increasing influent organic loading (Fig. 3a, 3b, 3c). At the beginning of the POAG formation on day 45 , the stable COD and $\mathrm{NH}_{4}{ }^{+}-\mathrm{N}$ removals were achieved and the time for POAS, AAG and AAS were around day 60 The average removal efficiencies of $\mathrm{COD}$ and $\mathrm{NH}_{4}{ }^{+}-\mathrm{N}$ by POAG were $91 \%$ and $84 \%$, respectively, which were $6 \%$ $20 \%$ and $4 \%-18 \%$ higher than those by POAS, AAG and AAS at the four stages (Fig. 3b, 3c) and also slightly higher than those of POAS, AAG and AAS under similar influent loading conditions reported in previous studies (Li et al., 2008; Moy et al., 2002; Rodríguez et al., 2012). Significant decrease in COD and $\mathrm{NH}_{4}{ }^{+}-\mathrm{N}$ removal by $\mathrm{AAG}$ and $\mathrm{AAS}$ were observed on day 68 with the influent loading of $3.60 \mathrm{~kg} \mathrm{COD} \mathrm{m}^{-3} \mathrm{~d}^{-1}$ and that for POAS was day 75 with influent loading of 4.57
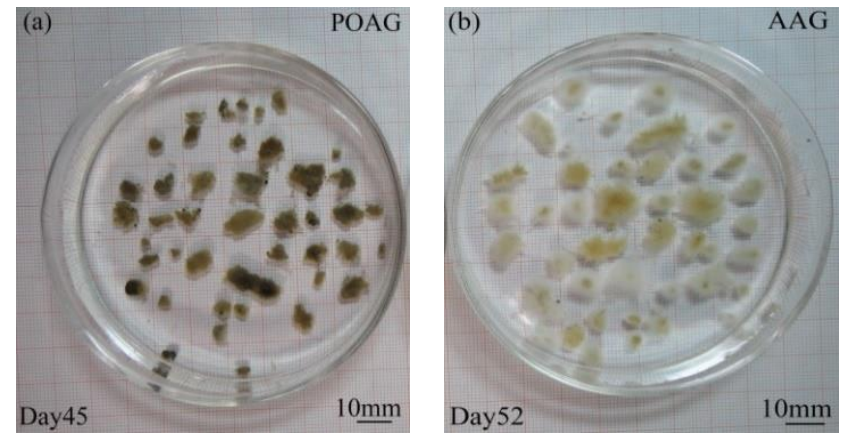
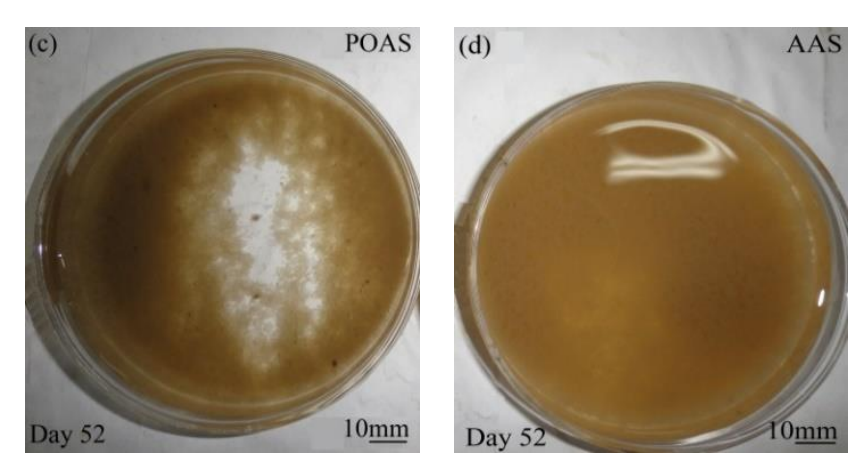

kg COD m $\mathrm{m}^{-3} \mathrm{~d}^{-1}$ (Fig. 3a, 3b, 3c), showing their instability in treating high-strength wastewater. A curve regression analysis between the removal efficiency of COD and influent loading was performed using SPSS 20.0 software. The theoretical removal efficiency of COD by POAG can peak at $95 \%(p<0.01, n=42)$, demonstrating the consistency with above experimental result. The SBRs aerated using pure-oxygen $(\mathrm{R} 1, \mathrm{R} 3)$ had high DO content with a range of 6-10 $\mathrm{mg} \mathrm{DO} \mathrm{L}^{-1}$ which were approximately three times of those for R2 and R4 system using air aeration with DO content of 2-4 mg DO L L pure-oxygen aeration is the prerequisite explaining the elevated performance (Rodríguez et al., 2010; 2011; 2012).

Figure 2. Photograph of the granules and sludge in four SBRs

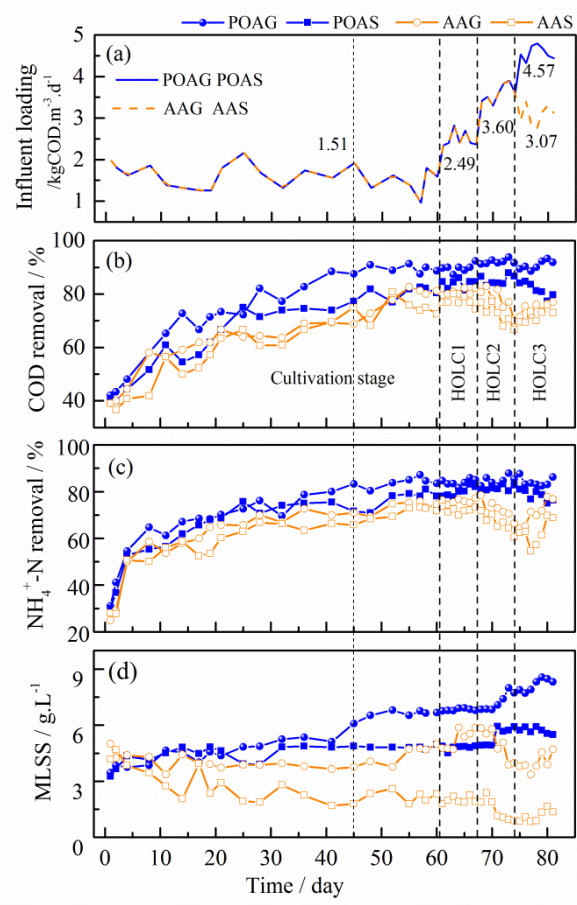

Figure 3. Performance of the four SBRs treating high organic loading wastewater (a) influent loading in terms of COD, (b) COD removal efficiency, (c) $\mathrm{NH}_{4}{ }^{+}-\mathrm{N}$ removal efficiency and (d) MLSS concentration 
endurance to HOLC due to high DO in R3. However, the presence of filamentous, actinophrys and nematode found in AAG (Fig. 4b $b_{5}, 4 b_{6}$ ) and AAS (Fig. 4d $d_{5}, 4 d_{6}$ ) at HOLC3 stage implied that poor effluent quality and instability of the operating system using air aeration under HOLC (Adav et al., 2010; Bernat et al., 2017; Pal et al., 2014).

Through SEM, bacteria were identified as the predominant microbial component in the POAG (Pan et al., 2014). The amount of bacteria in four SBRs during different stages is listed in Table 2. The highest number of aerobic bacteria observed in POAG accounted for $84 \%-92 \%$ of total bacteria followed by an order of POAS, AAG and AAS at corresponding stage, indicating strongest aerobic decomposition ability of POAG. A remarkable increasing trend for aerobic bacteria amount was found in POAG from cultivation stage to HOLC3 stage (Table 2). However, it decreased for POAS at HOLC3 stage, AAG and AAS at HOLC2 stage (Table 2). When the COD levels in R2 and R4 were altered from $3.60 \mathrm{~kg} \mathrm{COD} \mathrm{m}^{-3} \mathrm{~d}^{-1}$ to $3.07 \mathrm{~kg} \mathrm{COD} \mathrm{m}^{-3} \mathrm{~d}^{-1}$, the number of bacteria in AAG and AAS had a recovery increase (Table 2). The biomass of POAG, POAS, AAG and AAS in four SBRs under HOLC fluctuated from 6.8 to $8.6 \mathrm{~g} \mathrm{~L}^{-1}, 4.5$ to 5.9 $\mathrm{g} \mathrm{L}^{-1}, 3.3$ to $5.9 \mathrm{~g} \mathrm{~L}^{-1}$ and 0.9 to $2.4 \mathrm{~g} \mathrm{~L}^{-1}$, respectively. The results show that pure-oxygen aeration makes POAG harboring compact and sequential structure to promote high DO penetrated into the interior of granules and metabolic products expelled from inside (Meerburg et al., 2016; Zhao et al., 2016). It is favorable to aerobic bacteria growth in POAG (Adav et al., 2010; Bernat et al., 2017; Calderon et al., 2012; Chen et al., 2003), and endures high shock and perturbations from HOLC. The inference can be safely testified by the fact that the total biomass from cultivation stage to HOLC3 stage shows escalating trend identical to that of rising influent organic loading (Fig. 3d) and stable $\mathrm{COD}$ and $\mathrm{NH}_{4}{ }^{+}-\mathrm{N}$ removal performance (Fig. 3b, $3 c)$. However, the reverse is occurred for POAS, AAG and AAS (Fig. 3b, 3c, 3d).

Table 2. The number of bacteria in the four SBRs during different stages $\left(\times 10^{4}\right)$ CFU. $\mathrm{mL}^{-1}$

\begin{tabular}{|c|c|c|c|c|c|c|c|c|}
\hline \multirow{5}{*}{ Time/day } & \multicolumn{8}{|c|}{ Sample } \\
\hline & \multicolumn{2}{|c|}{ R1 (POAG) } & \multicolumn{2}{|c|}{ R2 (AAG) } & \multicolumn{2}{|c|}{ R3 (POAS) } & \multicolumn{2}{|c|}{ R4 (AAS) } \\
\hline & Aerobic & Anaerobic & Aerobic & Anaerobic & Aerobic & Anaerobic & Aerobic & Anaerobic \\
\hline & Bacteria & Bacteria & Bacteria & Bacteria & Bacteria & Bacteria & Bacteria & Bacteria \\
\hline & (Ave \pm S.D.) & (Ave \pm S.D.) & (Ave \pm S.D.) & (Ave \pm S.D.) & (Ave \pm S.D.) & (Ave \pm S.D.) & (Ave \pm S.D.) & (Ave \pm S.D.) \\
\hline Day 59 & $1323 \pm 101$ & $244 \pm 13$ & $619 \pm 21$ & $335 \pm 35$ & $1056 \pm 61$ & $187 \pm 24$ & $380 \pm 31$ & $300 \pm 19$ \\
\hline Day 67 & $1668 \pm 110$ & $264 \pm 19$ & $924 \pm 128$ & $654 \pm 74$ & $1445 \pm 122$ & $444 \pm 22$ & $621 \pm 58$ & $516 \pm 23$ \\
\hline Day 74 & $1973 \pm 135$ & $397 \pm 23$ & $656 \pm 82$ & $304 \pm 14$ & $1834 \pm 146$ & $185 \pm 10$ & $302 \pm 18$ & $113 \pm 15$ \\
\hline Day 81 & $2321 \pm 196$ & $190 \pm 24$ & $904 \pm 70$ & $356 \pm 25$ & $1684 \pm 132$ & $169 \pm 14$ & $543 \pm 37$ & $172 \pm 13$ \\
\hline
\end{tabular}
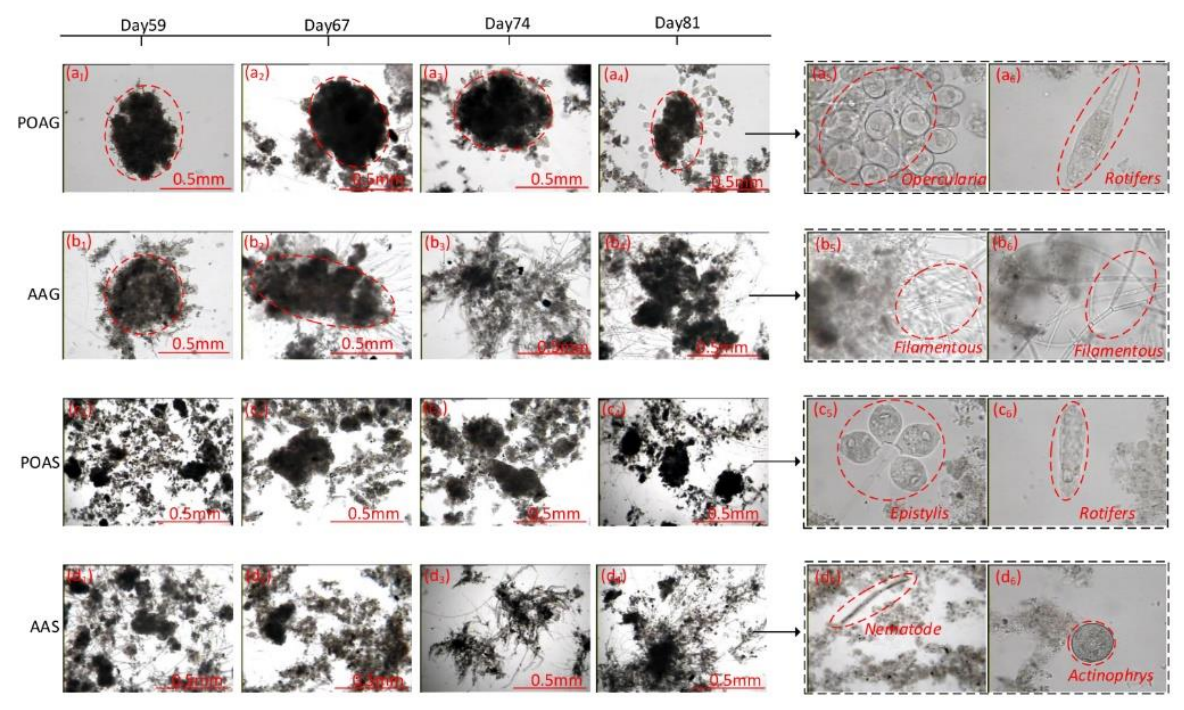

(10×magnification)

(40xmagnification)

Figure 4. Micromorphology of granules and sludge (10x magnification) and indicator microorganisms (40× magnification) in four SBRs observed by optical microscope 


\subsubsection{EPS content and its relationship with influent loading}

The accumulation of EPS as capsular material and peripheral slime has been correlated with biological adhesion and aggregation processes (Liu et al., 2004). The mature POAG had highest EPS content ranging from 169 $\mathrm{mg} \mathrm{g}^{-1}$ at the end of cultivation stage to $193 \mathrm{mg} \mathrm{g}^{-1}$ at HOLC3 stage, followed by $138 \mathrm{mg} \mathrm{g}^{-1}$ to $170 \mathrm{mg} \mathrm{g}^{-1}$ for POAS, 138 $\mathrm{mg} \mathrm{g}^{-1}$ to $127 \mathrm{mg} \mathrm{g}^{-1}$ for AAG, $117 \mathrm{mg} \mathrm{g}^{-1}$ to $105 \mathrm{mg} \mathrm{g}^{-1}$ for AAS at corresponding stages. High EPS content play an essential role in formation of POAG and maintaining the integrity and stability of spatial structure in mature POAG (Badireddy et al., 2010; Zhao et al., 2016). The variations of EPS for POAS, AAG and AAS are consistent with the trends of their biomass (Fig. 3d, 5a), indicating the loss of biomass due to less protection from EPS matrix and in turn, little EPS excretion from biomass under HOLC and low DO level. However, the rising EPS level is attributed to the elevated biomass in POAG and vice versa under HOLC (Fig. 5b).

A positive correlation is observed between influent COD concentration and the EPS content in POAG $\left(R^{2}=0.63\right.$, $\mathrm{p}<0.01$ ) (Fig. $5 \mathrm{c}$ ), and the coefficient is slightly lower for POAS $\left(R^{2}=0.58, p<0.01\right)$ (Fig. 5e). However, the increasing influent organic loading resulted in the decreasing the EPS excretion of AAG and AAS (Fig. 5d, 5f). Compared to conventional granule and activated sludge, POAG show great potential and capability in treating high organic wastewater due to high biomass retention in a microenvironment enveloped by EPS matrix, which gives POAG the ability to withstand high organic loading (Caudan et al., 2014; Zhu et al., 2012).
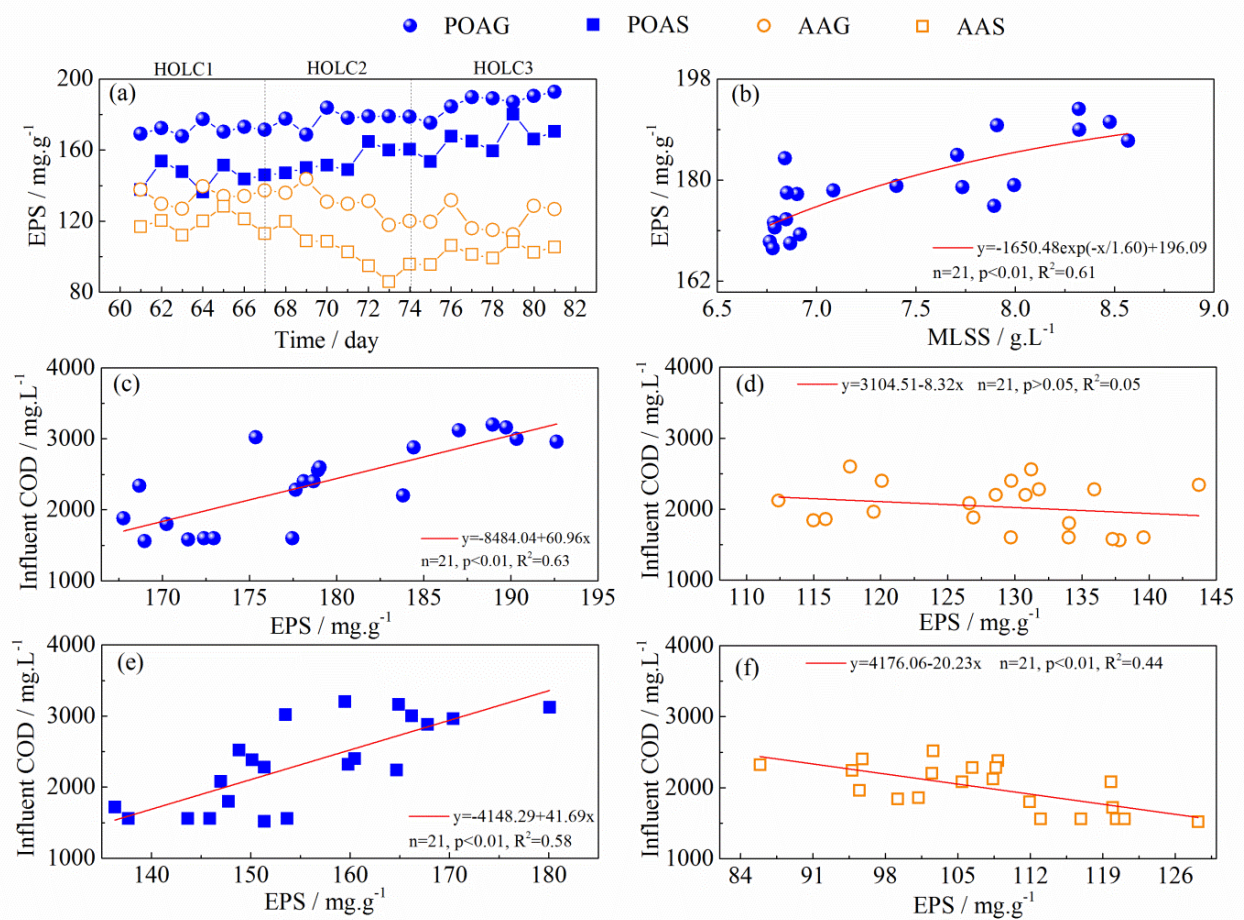

Figure 5. EPS content in four SBRs (a) EPS content with time, (b) correlation of EPS content with biomass in POAG, and relationship of EPS content with influent COD concentration in POAG (c), AAG (d), POAS (e) and AAS (f)

\subsubsection{Catalase activity and its relationship with influent loading}

Catalase is one of hydrolase in hydrolytic reaction which is believed to be the rate-limiting step in the overall process of organic matter degradation (Yao et al., 2010). The average activities of catalase for POAG, POAS, AAG and AAS at $\mathrm{HOLC}$ stages were $0.83 \mathrm{mgH}_{2} \mathrm{O}_{2} \mathrm{~g}^{-1} \mathrm{~min}^{-1}, 0.56 \mathrm{mgH}_{2} \mathrm{O}_{2} \mathrm{~g}^{-1}$ $\mathrm{min}^{-1}, 0.41 \mathrm{mgH}_{2} \mathrm{O}_{2} \mathrm{~g}^{-1} \mathrm{~min}^{-1}$ and $0.35 \mathrm{mgH}_{2} \mathrm{O}_{2} \mathrm{~g}^{-1} \mathrm{~min}^{-1}$, respectively. POAG had the highest activity of catalase with an increasing trend from the end of cultivation stage to
HOLC3 stage (Fig. 6a). The activities were found a decrease for POAS at the beginning of HOLC3 and, AAG and AAS at HOLC2 stage (Fig. 6a). The trends are identical to the variation of their biomass (Fig. 3d, 6a), showing weak ability of enzymatic excretion under HOLC and low DO condition. As for POAG, positive correlation between catalase and biomass (Fig. 6b) shows their mutual promoted effects, which ensures the ability to hydrolyze and mineralize organic substance under HOLC (Yao et al., 2010; 2012). 
The activity of catalase in POAG shows an increasing trend with the rising influent COD concentration $\left(R^{2}=0.76\right.$, $p<0.01$ ), whereas the coefficient for POAS is a little weak $\left(R^{2}=0.47, p<0.01\right)$ (Fig. 6c, 6e). It indicates that the activated sludge flocs, especially the POAG in the SBRs aerated using pure-oxygen have strong potential to enhance its capability of hydrolysis based on the level of HOLC (Yao et al., 2012). However, the reverses are occurred for AAG and AAS (Fig. $6 b, 6 d)$, which reflects the weak catalase excretion of conventional sludge flocs under HOLC (Li and Chróst, 2006; Yao et al., 2012). The aerobic process is critical for effective removal of organic pollutants, because enzymatic hydrolysis of organic compounds by microorganisms under aerobic conditions is more efficient than under anaerobic or anoxic conditions ( $\mathrm{Li}$ and Chróst, 2006). High catalase activity and DO in the POAG are the very important factors for keeping stable COD removal performance under HOLC.
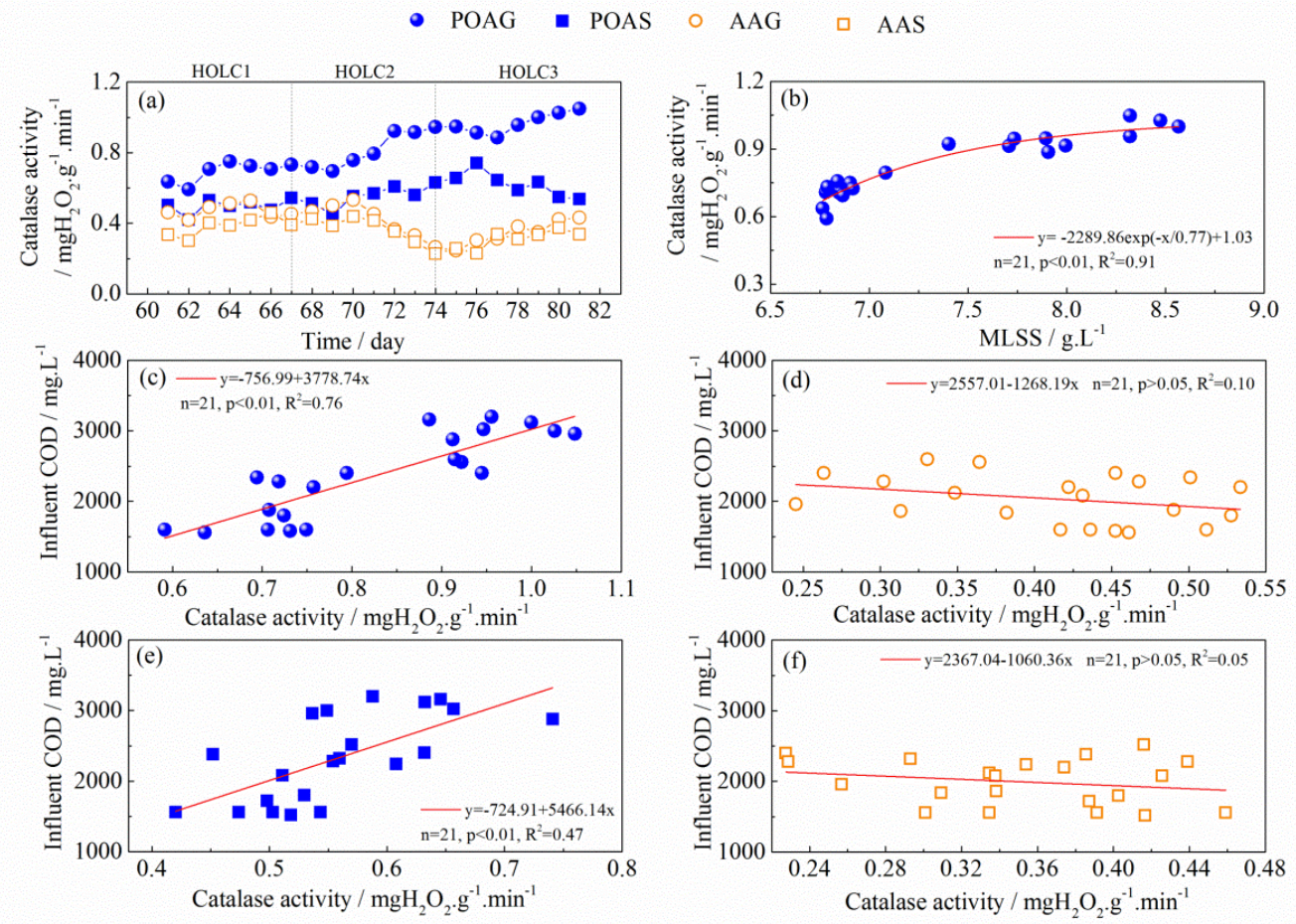

Figure 6. Catalase activity in four SBRs (a) catalase activity with time, (b) relation of catalase activity with biomass and correlation of catalase activity with influent COD concentration in POAG (c), AAG (d), POAS (e) and AAS (f)

\subsubsection{Dehydrogenase activity and its relationship with influent loading}

Dehydrogenase is the predominant enzyme in the respiratory electron-transport chain and its activity dominates the performance of activated sludge flocs in wastewater treatment (Matyja et al., 2016; Yao et al., 2010). POAG had highest activity of dehydrogenase with an average value of $195 \mathrm{mg} \mathrm{TF} \mathrm{g}^{-1} \mathrm{~h}^{-1}$ at HOLC stages, followed by $176 \mathrm{mg} \mathrm{TF} \mathrm{g}^{-1} \mathrm{~h}^{-1}$ for POAS, $85 \mathrm{mg} \mathrm{TF} \mathrm{g}^{-1} \mathrm{~h}^{-1}$ for AAG and $71 \mathrm{mg} \mathrm{TF} \mathrm{g}^{-1} \mathrm{~h}^{-1}$ for AAS. A rising trend of dehydrogenase activity in POAG followed by POAS was observed from the end of cultivation stage to HOLC3 stage (Fig. 7a). It was mainly due to the ascending biomass in the pure-oxygen aerated SBRs and vice versa through the stages (Fig. 7b). The increasing trends activity of dehydrogenase in AAG and AAS were broke off at HOLC3 (Fig. 7a). It was attributed to their weak endurance to high influent loading (3.60 kg COD $\mathrm{m}^{-3} \mathrm{~d}^{-1}$ ) under low DO condition at HOLC2 stage and the trends refreshed when the influent loading were decreased to $3.07 \mathrm{~kg} \mathrm{COD} \mathrm{m}^{-3} \mathrm{~d}^{-1}$.

Compared to above-mentioned EPS content and catalase activity, the dehydrogenase activity in AAG and AAS are not inhibited completely with influent loading increase (Fig. 7d, 7f). It is attributed to the dehydrogenase as an important indicator of microbial activity which plays a critical role in catalyzing the redox reactions in organisms under HOLC (Tarjányi-Szikora et al., 2013). The positive correlations between influent COD concentration and activity of dehydrogenase were observed in four SBRs following the order: POAG>POAS, AAG and AAS (Fig. 7c, 7d, 7e, 7f). It indicates that a great deal of dehydrogenase is secreted by POAG in pure-oxygen aerated SBR to carry out metabolism 
on account of an increase in influent organic loading (Tarjányi-Szikora et al., 2013; Zhang et al., 2016). There was the vigorous metabolism under HOLC, which in turn would enhance multiplication capacity of living organism in POAG and elevate removal performance of organic pollutants (Matyja et al., 2016; Zhang et al., 2016).


Figure 7. Dehydrogenase activity in four SBRs (a) dehydrogenase activity with time, (b) relation of dehydrogenase activity with biomass, and relationship of dehydrogenase activity with influent COD concentration

in POAG (c), AAG (d), POAS (e) and AAS ( $f$ )

\section{Conclusion}

The stable and mature POAG was successfully cultivated and was capable of consuming $\mathrm{COD}$ and $\mathrm{NH}_{4}{ }^{+}-\mathrm{N}$ as high as 91\% and $84 \%$, under HOLC. Compared with POAS, AAG and AAS, the POAG improve the efficiency of COD and $\mathrm{NH}_{4}{ }^{+}-\mathrm{N}$ removal by $6 \%-20 \%$ and $4 \%-18 \%$ at high organic loading. The sufficient DO is the crucial condition for POAG maintaining the high performance. The POAG have more compact structure and richer biomass production with increasing influent organic loading as compared to POAS, AAG and AAS. Meanwhile, the POAG synthesized high contents of EPS, catalase and dehydrogenase under HOLC, and the verse was true for POAS, AAG and AAS. The high EPS content are in favor of formation of POAG and maintaining the integrity and stability of spatial structure and, facilitating biomass growth in mature POAG. It can synthesize great amounts of catalase to hydrolyze and mineralize organic substance under HOLC. A great deal of dehydrogenase secreted by POAG are mainly responsible for the increasing vigorous metabolism, in turn enhancing multiplication capacity of living organism in POAG and elevating removal performance of organic pollutants. The biomass content and the enzymatic activities in POAG all show an increasing tendency with rising influent loading under HOLC and, at the same time, the removal efficiency of organic pollutants is stable, demonstrating great potential of POAG in wastewater treatment under HOLC.

\section{Acknowledgments}

We really appreciate the valuable comments from Prof. W.L. Huang and Prof. Y.B. Wang for the present version of the manuscript. This work was jointly supported by the Natural Science Foundation of Anhui Province (1608085MD82) and the Education Natural Science Foundation of Anhui Province (KJ2013A059).

\section{References}

Adav S.S., Lee D.J. and Lai J.Y. (2009), Functional consortium from aerobic granules under high organic loading rates, Bioresource Technology, 100(14), 3465-3470. 
Adav S.S., Lee D.J. and Lai J.Y. (2010), Potential cause of aerobic granular sludge breakdown at high organic loading rates, Applied Microbiology Biotechnology, 85(5), 1601-1610.

Adav S.S., Lee D.J. and Tay J.H. (2008), Extracellular polymeric substances and structural stability of aerobic granule, Water Research, 42(6-7), 1644-1650.

Amand L. and Carlsson B. (2012), Optimal aeration control in a nitrifying activated sludge process, Water Research, 46(7), 2101-2110.

APHA 2005. Standard Methods for the Examination of Water and Wastewater, American Public Health Association, Washington, DC.

Badireddy A.R., Chellam S., Gassman P.L., Engelhard M.H., Lea A.S. and Rosso K.M. (2010), Role of extracellular polymeric substances in bioflocculation of activated sludge microorganisms under glucose-controlled conditions, Water Research, 44(15), 4505-4516.

Bernat K., Kulikowska D. and Drzewicki A. (2017), Microfauna community during pulp and paper wastewater treatment in a UNOX system, European Jouranl Protistology, 58, 143-151.

Calderon K., Gonzalez-Martinez A., Montero-Puente C., Reboleiro-Rivas P., Poyatos J.M., Juarez-Jimenez B., MartinezToledo M.V. and Rodelas B. (2012), Bacterial community structure and enzyme activities in a membrane bioreactor (MBR) using pure oxygen as an aeration source, Bioresource Technology, 103(1), 87-94.

Caudan C., Filali A., Sperandio M. and Girbal-Neuhauser E. (2014), Multiple EPS interactions involved in the cohesion and structure of aerobic granules, Chemosphere, 117, 262-270.

Chen J.H., Hsu Y.C., Chen Y.F. and Lin C.C. (2003), Application of gas-inducing reactor to obtain high oxygen dissolution in aeration process, Water Research, 37(12), 2919-2928.

Farzadkia M., Vanani A.F., Golbaz S., Sajadi H.S. and Bazrafshan E. (2016), Characterization and evaluation of treatablility of wastewater generated in Khuzestan livestock slaughterhouses and assessing of their wastewater treatment systems, Global NEST Journal, 18(1), 108-118.

Li A.J., Yang S.F., Li X.Y. and Gu J.D. (2008), Microbial population dynamics during aerobic sludge granulation at different organic loading rates, Water Research, 42(13), 3552-3560.

Li Y. and Chróst R.J. (2006), Microbial enzymatic activities in aerobic activated sludge model reactors, Enzyme and Microbial Technology, 39(4), 568-572.

Liu Y.Q. and Tay J.H. (2015), Fast formation of aerobic granules by combining strong hydraulic selection pressure with overstressed organic loading rate, Water Research, 80,

256-266.
Liu Y.Q., Liu Y. and Tay J.H. (2004), The effects of extracellular polymeric substances on the formation and stability of biogranules, Applied Microbiology Biotechnology, 65(2), 143148.

Matyja K., Małachowska-Jutsz A., Mazur A.K. and Grabas K. (2016), Assessment of toxicity using dehydrogenases activity and mathematical modeling, Ecotoxicology, 25(5), 924-939.

Meerburg F.A., Vlaeminck S.E., Roume H., Seuntjens D., Pieper D.H., Jauregui R., Vilchez-Vargas R. and Boon N. (2016), Highrate activated sludge communities have a distinctly different structure compared to low-rate sludge communities, and are less sensitive towards environmental and operational variables, Water Research, 100, 137-145.

Moy B.Y., Tay J.H., Toh S.K., Liu Y. and Tay S.T.L. (2002), High organic loading influences the physical characteristics of aerobic sludge granules, Letters in Applied Microbiology, 34, 407-412.

Pal P., Khairnar K. and Paunikar W.N. (2014), Causes and remedies for filamentous foaming in activated sludge treatment plant, Global NEST Journal, 16(4), 762-772.

Pan F.H., Huang K.X., Jiang Y.B., Zhang X.X., Zhou F. and Hu X.B. (2014), Research on Activated Sludge Granulation and Its Structure in Pure Oxygen Aeration System, Journal of Anhui University of Technology (Natural Science), 31(4), 426-432 (in Chinese with an English abstract).

Ramos C., Suarez-Ojeda M.E. and Carrera J. (2016), Long-term performance and stability of a continuous granular airlift reactor treating a high-strength wastewater containing a mixture of aromatic compounds, Journal of Hazardous Materials, 303,154-161.

Rodríguez F.A., Martínez-Toledo M.V., González-López J., Hontoria E. and Poyatos J.M. (2010), Performance of benchscale membrane bioreactor under real work conditions using pure oxygen: viscosity and oxygen transfer analysis, Bioprocess and Biosystems Engineering, 33(7), 885-892.

Rodríguez F.A., Poyatos J.M., Reboleiro-Rivas P., Osorio F., González-López J. and Hontoria E. (2011), Kinetic study and oxygen transfer efficiency evaluation using respirometric methods in a submerged membrane bioreactor using pure oxygen to supply the aerobic conditions, Bioresource Technology, 102(10), 6013-6018.

Rodríguez F.A., Reboleiro-Rivas P., González-López J., Hontoria E. and Poyatos J.M. (2012), Comparative study of the use of pure oxygen and air in the nitrification of a MBR system used for wastewater treatment, Bioresource Technology, 121, 205211. 
Sajjad M. and Kim K.S. (2015), Studies on the interactions of $\mathrm{Ca}^{2+}$ and $\mathrm{Mg}^{2+}$ with EPS and their role in determining the physicochemical characteristics of granular sludges in SBR system, Process Biochemistry, 50(6), 966-972.

Tarjányi-Szikora S., Oláh J., Makó M., Palkó G., Barkács K. and Záray G. (2013), Comparison of different granular solids as biofilm carriers, Microchemical Journal, 107, 101-107.

Yao Y., Guan J., Tang P., Jiao H., Lin C., Wang J., Lu Z., Min H. and Gao H. (2010), Assessment of toxicity of tetrahydrofuran on the microbial community in activated sludge, Bioresource Technology, 101(14), 5213-5221.

Yao Y., Lu Z., Min H., Gao H. and Zhu F. (2012), The effect of tetrahydrofuran on the enzymatic activity and microbial community in activated sludge from a sequencing batch reactor, Ecotoxicology, 21(1), 56-65.

Zhang Z.Z., Xu J.J., Hu H.Y., Shi Z.J., Ji Z.Q., Deng R., Shi M.L. and Jin R.C. (2016), Insight into the short- and long-term effects of inorganic phosphate on anammox granule property, Bioresource Technology, 208, 161-169.

Zhao L., She Z., Jin C., Yang S., Guo L., Zhao Y. and Gao M. (2016), Characteristics of extracellular polymeric substances from sludge and biofilm in a simultaneous nitrification and denitrification system under high salinity stress, Bioprocess and Biosystems Engineering, 39(9), 1375-1389.

Zheng Y.M., Yu H.Q., Liu S.J. and Liu X.Z. (2006), Formation and instability of aerobic granules under high organic loading conditions, Chemosphere, 63(10), 1791-1800.

Zhu L., Qi H.Y., Lv M.L., Kong Y., Yu Y.W. and Xu X.Y. (2012), Component analysis of extracellular polymeric substances (EPS) during aerobic sludge granulation using FTIR and 3DEEM technologies, Bioresource Technology, 124, 455-459. 